\title{
IMAGES IN CLINICAL PRACTICE
}

\section{GENERALIZED DILATED SUPERFICIAL VEINS AND TELANGIECTASIA IN A NEWBORN INFANT}

Atika Caglar ${ }^{1}$, Nilay Hakan², Mustafa Aydinn ${ }^{1}$, Erdal Taskin ${ }^{1}$.

${ }^{1}$ Department of Neonatology, Firat University School of Medicine, Elazig, Turkey, ${ }^{2}$ Department Neonatology, Sitki Kocman University School of Medicine, Mugla, Turkey

A 39-year-old Caucasian woman delivered a male baby at the $38^{\text {th }}$ week of gestation. The neonate had a birth weight of $2.8 \mathrm{~kg}$ ( $5^{\text {th }}$ centile) and was born of $3^{\text {rd }}$-degree consanguineous marriage. On examination, the child had generalized dilated superficial veins, and telangiectasia involving the legs, arms, and trunk (Figure 1). The lesions spared the palms and soles. Systemic examination was normal. Ultrasonogram of the head and abdomen were normal. Echocardiogram of the heart revealed a secundum-type atrial septal defect and patent ductus arteriosus.

Figure 1. Skin shows generalized dilated superficial veins, and telangiectasia involving the legs, arms, and trunk

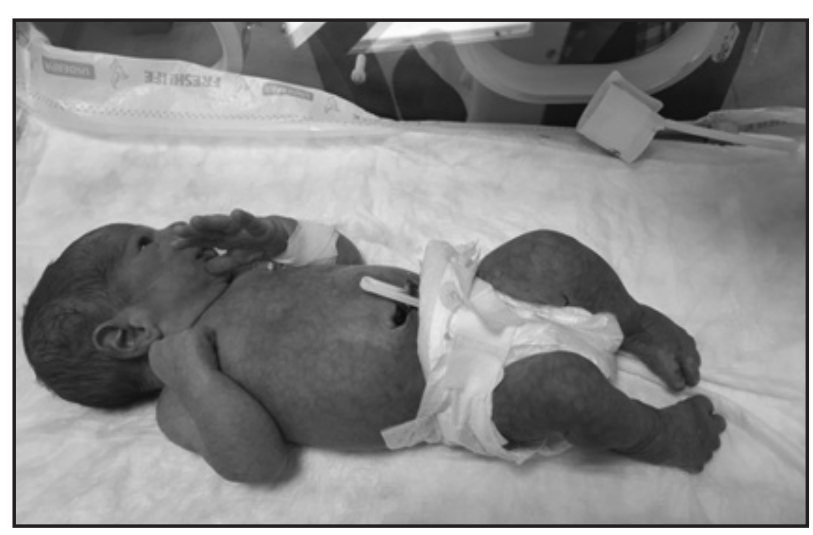

What is the diagnosis?

Cutis marmorata telangiectatica congenita (CMTC) or Van Lohuizen syndrome. It is an uncommon congenital vascular anomaly with unknown etiology. It is characterized by persistent cutis marmorata, telangiectasia, and phlebectasia. ${ }^{1}$ The cutaneous lesions commonly occur on the legs, arms, and trunk and rarely involve the face and scalp. Only 300 cases have been reported so far. ${ }^{2}$ The rate of anomalies reported in association with CMTC varies between $18.8 \%$ and $70 \%$ and most commonly reported anomalies are limb asymmetry and the coexistence of other vascular birthmarks. Other anomalies include glaucoma and macrocephaly. ${ }^{3}$ Cutaneous lesions improve with time, but skin ulceration and/or atrophy may develop over a period of time. ${ }^{4}$

\section{CONTACT Mustafa AYDIN}

Email: dr1mustafa@hotmail.com

Address for Correspondence: Mustafa AYDIN, MD, Department of Pediatrics-Neonatology, Firat University School of Medicine, 23119, Elazig / Turkey. (C)2019 Pediatric Oncall

\section{ARTICLE HISTORY}

Received 20 January 2019

Accepted 28 February 2019

\section{KEYWORDS}

vascular malformations, genodermatoses, neonate

\section{Compliance with Ethical Standards \\ Funding: None \\ Conflict of Interest: None}

\section{References :}

1. Van Lohuizen $\mathrm{CHJ}$. [Über eine seltene angeborene Hautanomalie (Cutis marmorata telangiectatica congenita)]. Acta Derm Venereol. 1922; 3: 2001-2011.

2. Wollina U, França K, Lotti T, Tchernev G. Van Lohuizen syndrome - a case report with a diagnostic delay of four years. Open Access Maced J Med Sci 2018; 6: 74-75.

3. Amitai DB, Fichman S, Merlob $\mathrm{P}$, Morad $\mathrm{Y}$, Lapidoth $\mathrm{M}$, Metzker A. Cutis marmorata telangiectatica congenita: clinical findings in 85 patients. Pediatr Dermatol. 2000; 1: $100-4$

4. Kienast AK, Hoeger PH. Cutis marmorata telangiectatica congenita: a prospective study of 27 cases and review of the literature with proposal of diagnostic criteria. Clin Exp Dermatol 2009; 34: 319-323. 